\title{
Medievalista
}

\section{Editorial revista Medievalista número 11}

José Mattoso

\section{(2) OpenEdition}

\section{Journals}

\section{Edição electrónica}

URL: http://journals.openedition.org/medievalista/739

DOI: 10.4000/medievalista.739

ISSN: 1646-740X

\section{Editora}

Instituto de Estudos Medievais - FCSH-UNL

\section{Edição impressa}

Data de publição: 1 janeiro 2012

\section{Refêrencia eletrónica}

José Mattoso, «Editorial revista Medievalista número 11 ». Medievalista [Online], 11 | 2012, posto

online no dia 21 fevereiro 2014, consultado o 22 setembro 2020. URL : http://journals.openedition.org/ medievalista/739; DOI : https://doi.org/10.4000/medievalista.739

\section{(c) (1) 8}

Mediavalista está licenciado com uma Licença Creative Commons - Atribuição-NãoComercial 4.0 Internacional. 
Título: Editorial. Medievalista número 11.

Autor(es): José Mattoso

Enquadramento Institucional: Director da Medievalista

Contacto:jjmtts@hotmail.com

Fonte: Medievalista [Em linha]. №10, (Janeiro-Junho 2012). Dir. José Mattoso. Lisboa:

IEM.

Disponível em: http://www2.fcsh.unl.pt/iem/medievalista/

ISSN: 1646-740X

\section{Editorial revista Medievalista número 11}

José Mattoso

A variedade de temas, de conceitos interpretativos e de metodologias continua a ser uma característica da revista online do IEM. Nesse sentido, representa bem o medievalismo português actual. Preferindo explorar temas e vias de representação historiográfica até há pouco virgens entre nós (ou pouco menos), do que aprofundar aspectos apenas aflorados em pesquisas anteriores, mas ainda não suficientemente dominados, os jovens investigadores mostram que também no medievalismo, como noutras ciências, se busca o progresso da investigação científica pelas vias da internacionalização e da interdisciplinaridade. 
Novidade absoluta no panorama medievalístico português é o artigo de Johni Langer sobre a representação iconográfica da morte de Odin em baixos-relevos das ilhas britânicas. De facto este artigo, vindo do Brasil, aborda um tema e utiliza fontes que ninguém em Portugal ousou jamais explorar. Exigia uma preparação especial na literatura nórdica dos séculos XII e XIII, praticamente desconhecida entre nós, e a exploração de documentos iconográficos que só uma preparação altamente especializada permita interpretar. É um convite a que também em Portugal se rompa com o hábito inveterado de estudar só questões relativas ao nosso país. Para isso, porém, é indispensável o contacto com instituições internacionais especializadas nomeadamente com centros norte-americanos recentes ou europeus mais antigos, mas pouco conhecidos. É significativo que os medievalistas brasileiros sigam o mesmo caminho que os americanos: livres de tradições anteriores por não terem um passado medieval, empreenderam investigações sobre temas que os europeus consideravam marginais e que não dependiam de levantamentos arquivísticos minuciosos. Novidade é também a disponibilização da base de dados das cantigas medievais galego-portuguesas, resultante de um projecto coordenado por Graça Videira Lopes no Instituto de Estudos Medievais, e de que neste número se dá notícia.

O desejo de originalidade inspirou igualmente outros três artigos baseados em documentação visual: o de Inês Correia sobre a figuração de São Jerónimo num manuscrito de Lorvão, o de Inês Lopes sobre os frescos quinhentistas de S. Francisco de Bragança e a tese de doutoramento de Catarina Barreira sobre as gárgulas portuguesas dos séculos XIII a XVI. O segundo segue a via especulativa, começando por discutir a validade do quadro interpretativo teórico oferecido pela antropologia estrutural, e situando-se antes na busca do sentido de motivos iconográficos próprios da época. Infelizmente o estado de conservação dos frescos retira alguma segurança à interpretação. O terceiro segue prudentemente a via clássica da constituição de um corpus claramente definido e a sua exploração sistemática de forma comparativa. Consegue assim conferir solidez ao significado que atribui a este tipo de esculturas, algo surpreendente do ponto de vista da cultura moderna que desvalorizou o grotesco. A apresentação da tese de Catarina Barreira é efectivamente um convite sedutor à leitura completa do seu texto. 
É também de documentos não escritos que Marco Liberato se ocupa. Aproveitando o material reunido recentemente por várias escavações arqueológico de Santarém, e cruzando-o com algumas informações escritas em textos conhecidos, mas não aproveitados até hoje, o autor reconstitui os dados essenciais da paisagem urbana da mesma cidade nos séculos VIII a XII.

Os outros artigos deste número da Medievalista seguem métodos mais habituais, embora concentrando-se em dados pouco ou nada explorados até hoje: a produção têxtil feminina nos séculos XIV e XV, por Joana Sequeira e Arnaldo Melo; os judeus de Viseu por Anísio Saraiva; as opiniões económico-políticas de Ibn Kaldun analisadas de um ponto de vista marxista; e os primórdios da sigilografa portuguesa (século XII). Não posso deixar de sublinhar o interesse do primeiro para a história da produção e comercialização artesanal - assunto que os autores da história económica têm esquecido quase por completo e acerca do qual não se esperavam tantas informações como a que os autores conseguiram reunir. Aponto também as novidades do segundo, por dar a conhecer aspectos peculiares das comunas judaicas graças à relativa abundância de dados fornecidos pela documentação inédita de Viseu. E do quarto, que explora o quadro em que poderia ter nascido a sigilografia real portuguesa por comparação com os raros selos concretamente referenciados em Portugal e datados antes de 1185.

Destaque-se ainda o texto de Armando Luís de Carvalho Homem, a propósito do desaparecimento de Bernard Guenée, e que constitui muito mais do que uma nota evocativa, sublinhando a grande relevância deste autor no panorama da história institucional medieval.

Resta-me referir a importância da tese de doutoramento de Luísa Trindade acerca da história do urbanismo português do século XIII, da qual se apresenta uma recensão bibliográfica. Sendo a história das cidades medievais portuguesas uma matéria amplamente estudada, faltava-nos por completo uma história das estruturas urbanas susceptível de enquadrar os fenómenos relacionados com o desempenho das funções urbanas e a sua evolução na época medieval. O método seguido, ao conjugar a observação documental com a análise das plantas de um grupo escolhido de povoações, 
mostra plenamente as virtualidades de uma abordagem interdisciplinar dos testemunhos disponíveis, escritos e não escritos.

\section{COMO CITAR ESTE ARTIGO}

\section{Referência electrónica:}

MATTOSO, José - Editorial revista Medievalista número 11. Medievalista [Em linha].

No11, (Janeiro-Junho de 2012). [Consultado dd.mm.aaaa]. Disponível em http://www2.fcsh.unl.pt/iem/medievalista/MEDIEVALISTA11 Imattoso1101.html. ISSN 1646-740X.

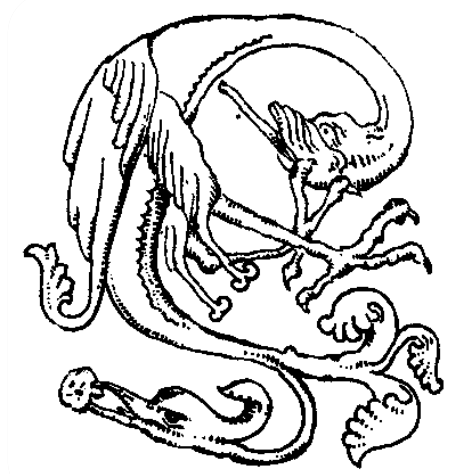

